\title{
Hormesis method for increasing oat straw with a view to viability of direct-seeding systems ${ }^{1}$
}

\author{
Método hormesis para o aumento da palhada de aveia preta visando à viabilidade do \\ sistema de plantio direto
}

\author{
Leandro Augusto Felix Tavares ${ }^{2 *}$, Saulo Fernando Gomes Sousa ${ }^{3}$, Tiago Pereira da Silva Correia ${ }^{3}$, Paulo Roberto \\ Arbex Silva ${ }^{3}$ e Edivaldo Domingues Velini ${ }^{3}$
}

\begin{abstract}
In conservation agriculture, mainly under direct seeding, maintaining the vegetation ground cover is essential, since this serves as a reservoir of nutrients which are slowly released to plants by microorganisms. Some authors have sought to study increases in the amount of straw in the soil, in addition to slowing down the process of decomposition, with hormesis being one of the techniques used. This technique states that all chemical substances are both poisonous and nonpoisonous, with only the dosage determining whether they are lethal or not. This study aimed to evaluate the dry weight and agronomic characteristics of a crop of black oat subjected to hormesis. The experimental design was of randomised blocks, with 12 treatments and 4 replications, giving a total of 48 experimental lots. The treatments were: Haloxyfop-R Methyl Ester at dosages of $0.625,1.25$ and $2.50 \mathrm{~g} \mathrm{ha}^{-1}$; Glyphosate at dosages of 12.50, 25.00 and $50.00 \mathrm{~g} \mathrm{ha}^{-1}$; 2,4-D dimethylamine salt at dosages of 100.00, 200.00 and $300.00 \mathrm{~g} \mathrm{ha}^{-1}$; Alterbane at a dosage of $500.00 \mathrm{~g} \mathrm{ha}^{-1}$; Salicylic acid at a dose of $100 \mathrm{~g} \mathrm{ha}^{-1}$; and a control. It was concluded that for the subdosages under test, the herbicides 2,4-D at medium dosage and Verdict at low dosage were shown to be the best treatments for conserving straw as ground cover under direct seeding.
\end{abstract}

Key words: Sustainability. Vegetation cover. Direct-seeding systems.

\begin{abstract}
RESUMO - Na agricultura conservacionista, principalmente no plantio direto, a manutenção da cobertura vegetal sobre o solo é essencial, pois esta funciona como reservatório de nutrientes que lentamente serão liberados para as plantas através de microrganismos. Alguns autores têm procurado estudos para aumentar a quantidade de palha presente no solo, além de desacelerar seu processo de decomposição, sendo uma das técnicas utilizadas a hormesis. Essa técnica diz que todas as substâncias químicas são veneno e não veneno, o que faz dela letal ou não, é apenas a dosagem. O trabalho teve como objetivo avaliar a matéria seca e as características agronômicas da cultura da aveia preta submetida à hormesis. O delineamento experimental foi em blocos casualizados com 12 tratamentos e 4 repetições, totalizando 48 parcelas

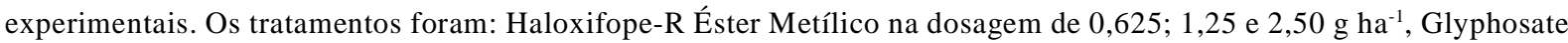
na dosagem de 12,$50 ; 25,00$ e 50,00 $\mathrm{g} \mathrm{ha}^{-1},(2,4-\mathrm{D})$ Sal Dimetilamina na dosagem de 100,00; 200,00 e 300,00 $\mathrm{g} \mathrm{ha}^{-1}$, Alterbane na dosagem de 500,00 $\mathrm{g} \mathrm{ha}^{-1}$, Ácido salicílico na dosagem de $100 \mathrm{~g} \mathrm{ha}^{-1}$ além de uma testemunha. Concluiu-se que nas subdosagens testadas, os herbicidas 2,4 D na dosagem média e Verdict na dosagem baixa, apresentaram-se como melhores tratamentos para a conservação de palha no solo sob plantio direto.
\end{abstract}

Palavras-chave: Sustentabilidade. Cobertura vegetal. Sistemas de plantio direto.

\footnotetext{
Autor para correspondência

${ }^{1}$ Recebido para publicação em 12/06/2013; aprovado em 23/10/2014

Trabalho realizado com recursos da Faculdade de Ciências Agronômicas da UNESP/Botucatu

${ }^{2}$ Instituto de Ciências Agrárias, Universidade Federal dos Vales do Jequitinhonha e Mucuri, Unaí-MG, Brasil, leandro.tavares@ufvjm.edu.br

${ }^{3}$ Faculdade de Ciências Agronômicas, Universidade Estadual Paulista Júlio de Mesquita Filho, Botucatu-SP, Brasil, saulo@fca.unesp.br, tiago@fca.unesp.br, arbex@fca.unesp.br, velini@fca.unesp.br
} 


\section{INTRODUCTION}

The system of direct seeding is a technique of conservation farming where sowing is carried out without the ploughing and harrowing stages of conventional preparation. For this technique it is necessary to keep the soil always covered with growing plants and crop residue in order to prevent increasing soil erosion (CRUZ, 2008).

This system is based on the production of a large amount of plant mass to cover the soil, on preventing water erosion, on the conservation and improvement of the physical, chemical and biological characteristics of the soil, and on the increase in its water storage capacity (SILVA et al., 2006).

In regions with higher average temperatures, there is great difficulty in implementing direct seeding, due to the difficulty of keeping straw on the ground from one year to another, as it decomposes very quickly (ANDREOTTI et al., 2008).

Pires et al. (2008), state that good ground cover should promote the suppression of weeds, as this can lower the costs of control during post-emergence in commercial, spring-summer crops.

According to Sá et al. (2010), root development in maize plants benefits from an increase in oat straw in both the surface layer ( 0 to $0.20 \mathrm{~m}$ ) and the subsurface layer ( 0.50 than $1,00 \mathrm{~m})$ of the soil.

The direct-seeding system is a conservational soil management system and so is directly related to biomass left on the ground. The system keeps crop residues on the soil surface, being an important technique for maintaining and restoring the productive capacity of soils, both under conventional management and of degraded areas (TORRES et al., 2005).

To this end, some authors have sought to study how to have straw remain longer as ground cover, besides also increasing the amount of dry matter during production.

One of the techniques that has been employed is known as the Hormesis technique. This teaches that all chemical substances are both poisonous and nonpoisonous, and that it is only the dosage which determines whether they are lethal or not.

Velini (2006) found that glyphosate causes hormesis in quite distinct crops and species, such as sorghum, soybeans, coffee, eucalyptus, peanuts, maize and pine (Pinus spp.) In general, the response had a more pronounced hormetic effect in woody species, such as Eucalyptus spp. Other authors have observed hormesis with glyphosate in maize crops (SCHABENBERGER et al., 1999) and Echinochloa crus-pavonis (WAGNER et al., 2003).
The fact that many herbicides were originally developed as growth regulators, demonstrates the hypothesis of hormesis. Such was the case with glyphosate, whose predecessor, glyphosine, was a compound used as a growth regulator. This herbicide particularly has presented a hormetic effect on various plants, such as increased green matter in maize (WAGNER, 2003), an increase in root dry weight in the soybean (GODOY, 2007) and in the phosphorus content of the leaves of the eucalyptus (CARBONARI et al., 2007).

The hormetic effect is observed in all groups of organisms, such as bacteria and fungi, higher plants and animals (CALABRESE, 2005). It may become a tool to be employed in agriculture in general.

The aim of this study therefore was to evaluate the dry matter and agronomic characteristics of a crop of black oats submitted to hormesis.

\section{MATERIAL AND METHODS}

The test was carried out in the winter of 2011, at the Lageado Experimental Farm of the School of Agricultural Sciences at UNESP in Botucatu, in the mid-west region of the state of São Paulo, Brazil. The approximate geographical coordinates are $22^{\circ} 51^{\prime} \mathrm{S}$ and $48^{\circ} 26^{\prime} \mathrm{W}$, at an average elevation of 770 meters; the climate is rainy subtropical, with dry winters, type $\mathrm{Cfa}$, according to the Köppen system of classification.

The experiment consisted of 11 treatments and one control, each with four replications, giving a total of 48 lots divided into four randomised blocks (Figure 1).

The results obtained were subjected to variance analysis and tested for contrasts. For comparison of the treatment means with the control, Dunnett's test was used at 5\% significance. For comparison of the treatment means between themselves, the Scheffé test at 5\% significance was used.

According to Vieira and Hoffmann (1989), Dunnett's test should be applied every time it is wanted to compare the treatment means to the control mean only. The Scheffé test should be applied only when the F-test gives significant results. If the value obtained for F is not significant, no contrast would be significant, and therefore application of the Scheffé test is not justified.

In the field, the lots were $10 \mathrm{~m}$ long by $4 \mathrm{~m}$ wide. Between each lot a space, $5 \mathrm{~m}$ by $3 \mathrm{~m}$, was left as a border. 
Figure 1 - Layout of the arrangement of treatments and blocks in the field

\begin{tabular}{|c|c|c|c|c|c|c|c|c|c|c|c|}
\hline SA & $\mathrm{C}$ & $\mathrm{VD} 2$ & $\mathrm{GD} 3$ & $2.4 \mathrm{D} 1$ & $\mathrm{VD} 1$ & $2.4 \mathrm{D} 3$ & $2.4 \mathrm{D} 2$ & $\mathrm{GD} 1$ & $\mathrm{GD} 2$ & $\mathrm{VD} 3$ & $\mathrm{~A}$ \\
\hline $2.4 \mathrm{D} 3$ & $2.4 \mathrm{D} 2$ & $\mathrm{VD} 3$ & $\mathrm{SA}$ & $\mathrm{C}$ & $\mathrm{GD} 1$ & $\mathrm{GD} 3$ & $\mathrm{GD} 2$ & $\mathrm{~A}$ & $\mathrm{VD} 2$ & $2.4 \mathrm{D} 1$ & $2.4 \mathrm{D} 2$ \\
\hline $\mathrm{GD} 1$ & $\mathrm{VD} 1$ & $2.4 \mathrm{D} 1$ & $\mathrm{GD} 2$ & $\mathrm{VD} 1$ & $\mathrm{~A}$ & $\mathrm{C}$ & $\mathrm{VD} 3$ & $\mathrm{VD} 2$ & $\mathrm{SA}$ & $2.4 \mathrm{D} 3$ & $\mathrm{GD} 3$ \\
\hline $\mathrm{VD} 3$ & $\mathrm{GD} 1$ & $\mathrm{GD} 3$ & $\mathrm{VD} 2$ & $2.4 \mathrm{D} 2$ & $\mathrm{SA}$ & $2.4 \mathrm{D} 3$ & $2.4 \mathrm{D} 1$ & $\mathrm{~A}$ & $\mathrm{VD} 1$ & $\mathrm{C}$ & $\mathrm{GD} 2$ \\
\hline
\end{tabular}

where C: control (no application); A: Alterbane; SA: Salicylic Acid; GD1: Glyphosate dosage 1 (low); GD2: Glyphosate dosage 2 (medium); GD3: Glyphosate dosage 3 (high); 2.4D1: 2.4 D dosage 1 (low); 2.4D2: 2.4 D dosage 2 (medium); 2.4D3: 2.4 D dosage 3 (high); VD1: Verdict dosage 1 (low); VD2: Verdict dosage 2 (medium); VD3: Verdict dosage 3 (high).

To find the dosages to be applied in each treatment (Table 1), the oat crop underwent tests in the greenhouse, where several subdosages were tested. The results ranged from no result for the lowest subdosages to death at the higher dosages; the three dosages giving the most results were used in this study.

To spray the herbicides in the lots, a $\mathrm{CO}_{2}$ pressurized backpack sprayer was used, maintaining a

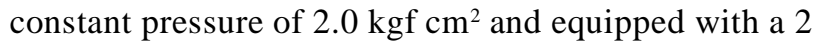
metre spray bar and four 02 XR 110 VS spray nozzles spaced $0.5 \mathrm{~m}$ apart.

In each experimental lot, $3 \mathrm{~m}$ were marked out so that there were three rows in each lot where all the evaluations for the area were carried out; the remainder of the lot was used as a border.

To carry out the evaluations, all the plants in the three metres marked out in each lot were collected, and the number of plants, plant dry matter, crop production, number of panicles and panicle size for each plant were evaluated.
Plant height was measured using a graduated ruler, measuring from the ground to the limit of the sheath of the last leaf on the plant.

Once collected, the plants were taken to the Laboratory for Plantability of the Direct Seeding Group of FCA, at UNESP, Botucatu, where the panicle size for the crop was counted and measured using a graduated ruler.

After harvesting, the plants were dried in a forcedair circulation oven at a temperature of $60{ }^{\circ} \mathrm{C}$ for 48 hours. The dry matter was then quantified for each plot.

\section{RESULTS AND DISCUSSION}

There was a significant effect from the application of subdosages on the dry matter and productivity of the oat crop (Table 2).

Verifying the test for contrasts (Table 3) for the variables of productivity and dry matter, it can be seen

Table 1 - Details of the treatments applied to the black oats

\begin{tabular}{lccccc}
\hline \multirow{2}{*}{ Dosage $\left(\mathrm{g} \mathrm{ha}^{-1}\right)$} & \multicolumn{5}{c}{ Active Ingredients } \\
\cline { 2 - 5 } & Verdict & Glyphosate & $(2.4-\mathrm{D})$ & Alterbane & Salisylic acid \\
\hline 1 & 0.625 & 12.50 & 100.00 & 500.00 & 100.00 \\
2 & 1.250 & 25.00 & 200.00 & & \\
3 & 2.500 & 50.00 & 300.00 & & \\
\hline
\end{tabular}


Table 2 - Summary of the variance analysis (Scheffé test) and results for mean plant height, panicle length, number of nodes per panicle, dry matter and productivity in oats, as a function of herbicide subdosages

\begin{tabular}{lccrc}
\hline \multicolumn{1}{c}{ Cause of variation } & F-test & D.F & S.S & CV (\%) \\
\hline Plant height & $2.4^{\text {ns }}$ & 11 & 76.96 & 4.01 \\
Panicle length & $3.54^{\mathrm{ns}}$ & 11 & 22.36 & 6.23 \\
Nbr of panicle nodes & $1.08^{\mathrm{ns}}$ & 11 & 2.00 & 4.69 \\
Dry matter & $6.30^{*}$ & 11 & 30947243 & 16.67 \\
Productivity & $7.53^{*}$ & 11 & 70659.71 & 14.52 \\
\hline
\end{tabular}

*significant at $p<0.05$ by Scheffé test; ns: not significant; D.F = Degrees of freedom; S.S = Sum of squares; CV = Coeficient of variation. Due to the test for contrasts, all values for $\mathrm{F}$ are quadratic

Table 3 - Test for contrasts of the mean results for productivity in the crop of black oats

\begin{tabular}{ccccc}
\hline \multicolumn{1}{c}{ Variable } & & Contrast Value & Valor of t & p-value \\
\hline \multirow{2}{*}{ Productivity } & Assume equal variances & 360.5 & 7.309 & 0.000 \\
& Do not assume equal variances & 360.5 & 7.243 & 0.000 \\
\hline \multirow{2}{*}{ Dy matter } & Assume equal variances & 3268.75 & 6.258 & 0.000 \\
& Do not assume equal variances & 3268.75 & 4.767 & 0.008 \\
\hline
\end{tabular}

that the p-value was equal to zero. In both cases there is significance, so that when applying subdosages of some herbicides, significantly different means for productivity and dry matter are generated.

Verifying the comparison of treatment averages for productivity (Table 4), it can be seen that there is a significant effect for the treatments, Verdict, at medium and high dosages, as well as Salicylic Acid. The treatment employing the herbicide Verdict at high dosage showed a better response compared to the control, with an increase of $130.5 \mathrm{~kg} \mathrm{ha}^{-1}$.

It can be seen that the treatment with Glyphosate at average dosage was shown to inhibit productivity of the black oat crop, presenting an average decrease of $13.25 \mathrm{~kg} \mathrm{ha}^{-1}$ compared to the control.

Looking at the comparison between the treatment averages and the control (Table 5), it appears that there was a significant effect by Dunnett's test for the treatment

Table 4 - Comparison by Dunnett's test of mean productivity $\left(\mathrm{kg} \mathrm{ha}^{-1}\right)$ for the treatments and the control

\begin{tabular}{lcccc}
\hline Treatment & Mean difference & p-value & Upper confidence interval & Lower confidence interval \\
\hline GD 1 & $10.5^{\mathrm{ns}}$ & 0.912 & 11.229 & -5.229 \\
GD 2 & $-13.25^{\mathrm{ns}}$ & 1.000 & 6.904 & -9.554 \\
GD 3 & $30^{\mathrm{ns}}$ & 1.000 & 9.279 & -7.179 \\
2.4 D 1 & $71.25^{\mathrm{ns}}$ & 0.118 & 15.354 & -11.047 \\
2.4 D 2 & $35.75^{\mathrm{ns}}$ & 0.802 & 11.804 & -4.654 \\
2.4 D 3 & $71.25^{\mathrm{ns}}$ & 0.263 & 14.279 & -2.279 \\
VD 1 & $-6.75^{\mathrm{ns}}$ & 1.000 & 7.554 & -8.904 \\
VD 2 & $106^{*}$ & 0.006 & 18.829 & 2.370 \\
VD 3 & $130.5^{*}$ & 0.001 & 21.279 & 4.820 \\
SA & $104^{*}$ & 0.007 & 18.629 & 2.170 \\
Alterbane (A) & $46.75^{\mathrm{ns}}$ & 0.529 & 12.904 & -3.554 \\
\hline
\end{tabular}

${ }^{\mathrm{n} s}$ not significant; *significant at $p<0.05$ by Dunnett's test 
Table 5 - Comparison by Dunnett's test of mean dry matter $\left(\mathrm{kg} \mathrm{ha}^{-1}\right)$ for the treatments compared to the control

\begin{tabular}{lcccc}
\hline \multicolumn{1}{c}{ Treatment } & Mean difference & p-value & Upper confidence interval & Lower confidence interval \\
\hline GD 1 & $122.5^{\text {ns }}$ & 0.999 & 1.631 & -1.386 \\
GD 2 & $-1000.75^{\text {ns }}$ & 0.352 & 508.743 & -2.510 \\
GD 3 & $-2360.25^{*}$ & 0.001 & -850.756 & -3.869 \\
2.4 D 1 & $-311.75^{\text {ns }}$ & 0.994 & 1.197 & -1.821 \\
2.4 D 2 & $908.50^{\text {ns }}$ & 0.461 & 2.417 & -600.993 \\
2.4 D 3 & $-1427^{\text {ns }}$ & 0.071 & 8.249 & -2.936 \\
VD 1 & $-501.75^{\text {ns }}$ & 0.947 & 1.007 & -2.011 \\
VD 2 & $-387.75^{\text {ns }}$ & 0.99 & 1.121 & -1.897 \\
VD 3 & $-1200^{\text {ns }}$ & 0.174 & 309.343 & -2.709 \\
SA & $50.25^{\text {ns }}$ & 1.000 & 1.559 & -1.459 \\
Alterbane $(A)$ & $-834.75^{\text {ns }}$ & 0.155 & 674.743 & -2.344 \\
\hline
\end{tabular}

${ }_{\text {ns }}$ not significant; *significant at $p<0.05$ by Dunnett's test

using Glyphosate at high dosage, which suggests a decrease in dry matter compared to the control.

The data for dry matter in the crop (Table 6) showed a statistical difference between treatments, where it can be seen that the treatment with Glyphosate at high dosage (Glyphosate 3) was the treatment which gave the lowest increase in dry matter, whereas the treatment using $2.4 \mathrm{D}$ at medium dosage (2.4 D 2) had the highest increase in dry matter, of the order of 7,789.75 $\mathrm{kg} \mathrm{ha}^{-1}$. This result demonstrates that application of the product caused stress to the plant, stimulating an increase in dry matter.

Table 6 - Comparison between treatments for the evaluation of dry matter $\left(\mathrm{kg} \mathrm{ha}^{-1}\right)$ in the black oat crop

\begin{tabular}{lc}
\hline \multicolumn{1}{c}{ Treatment } & Dry Matter $\left(\mathrm{kg} \mathrm{ha}^{-1}\right)$ \\
\hline GD 1 & $7003.75 \mathrm{AB}$ \\
GD 2 & $5880.5 \mathrm{AB}$ \\
GD 3 & $4521 \mathrm{~B}$ \\
$2.4 \mathrm{D} 1$ & $6569.5 \mathrm{AB}$ \\
$2.4 \mathrm{D} 2$ & $7789.7 \mathrm{~A}$ \\
$2.4 \mathrm{D} 3$ & $5454.2 \mathrm{AB}$ \\
VD 1 & $6379.5 \mathrm{AB}$ \\
VD 2 & $6493.5 \mathrm{AB}$ \\
VD 3 & $5681.2 \mathrm{AB}$ \\
SA & $6931.5 \mathrm{AB}$ \\
Alterbane (A) & $6046.5 \mathrm{AB}$ \\
Control (no application) & $6881.2 \mathrm{AB}$ \\
\hline
\end{tabular}

Means followed by the same letter in the column do not differ at $5 \%$ by Scheffé's test
When compared with the control (no application), the treatment with $2.4 \mathrm{D}$ at medium-dosage (2.4 D 2) showed an increase of $908.5 \mathrm{~kg} \mathrm{ha}^{-1}$, a similar result to that found by Silva et al. (2010) who, when working with maize, found that the application of any herbicide at the recommended dosage positively affects the production of dry matter in relation to treatments with no application or of hand weeding. According to the authors, such applications do not affect the crop due to its tolerance to herbicides, giving more effective control of weeds, and thus reducing competition for water, light and nutrients.

In Table 7 can be seen the results for productivity of the crop of black oats for the different treatments. The treatment with the highest productivity was Verdict at low dosage (VD 1), with a productivity of $482 \mathrm{~kg} \mathrm{ha}^{-1}$. Whereas the treatment with Glyphosate at medium-dosage (GD 2) had the lowest productivity. When the treatment with Verdict at low dosage (RV 1) is compared to the control, an increase of $131 \mathrm{~kg} \mathrm{ha}^{-1}$ can be seen. This result has the same origin as the result found for dry matter, but in this case with a different herbicide.

Silva et al. (2012) evaluated a bean crop subjected to the application of subdosages of Glyphosate, testing three bean cultivars; in none of them was productivity affected.

Figueiredo et al. (2007) found that the application of subdosages of the $378 \mathrm{~g} \mathrm{ha}^{-1}$ dosage of glyphosate, adversely affects development and production in the tomato.

On the other hand, Velini et al. (2008) found stimulated growth in soybeans, maize, Eucalyptus grandis, Pinus caribea and Commelina benghalinsis when subdosages of glyphosate were applied to these crops. The authors also emphasised that different dosages were used for each crop. 
Table 7 - Comparison between treatments for productivity in the black oat crop

\begin{tabular}{lc}
\hline Treatment & Productivity $\left(\mathrm{kg} \mathrm{ha}^{-1}\right)$ \\
\hline GD 1 & $381.5 \mathrm{AB}$ \\
GD 2 & $338.2 \mathrm{~B}$ \\
GD 3 & $362.0 \mathrm{AB}$ \\
$2.4 \mathrm{D} 1$ & $422.7 \mathrm{AB}$ \\
$2.4 \mathrm{D} 2$ & $387.2 \mathrm{AB}$ \\
$2.4 \mathrm{D} 3$ & $411.0 \mathrm{AB}$ \\
VD 1 & $482.0 \mathrm{~A}$ \\
VD 2 & $457.5 \mathrm{AB}$ \\
VD 3 & $344.7 \mathrm{~B}$ \\
AS & $455.5 \mathrm{AB}$ \\
Alterbane (A) & $398.2 \mathrm{AB}$ \\
Control (no application) & $351.5 \mathrm{AB}$ \\
\hline
\end{tabular}

Means followed by the same letter in the column do not differ at 5\% by Scheffé's test

\section{CONCLUSIONS}

1. At the subdosages under test, the herbicides, $2.4 \mathrm{D}$ at medium dosage, and Verdict at low dosage, appeared to be the best treatments for the viability of direct seeding in regions which present difficulties of straw production;

2. The herbicides, 2.4 D at medium dosage, and Verdict at low dosage, significantly increased the dry matter and productivity of the black oat crop respectively;

3. Treatment with the herbicide Glyphosate was shown to inhibit dry matter and productivity in the black oat crop.

\section{REFERENCES}

ANDREOTTI, M. et al. Produtividade do milho safrinha e modificações químicas de um latossolo em sistema plantio direto em função de espécies e cobertura após calagem superficial. Acta Scientiarum Agronomy, v. 30, n. 01, p. 109-115, 2008.

CALABRESE, E. J. Paradigm lost, paradigm found: The reemergence of hormesis as a fundamental dose response model in the toxicological sciences. Environ. Pollution, Geneva, n. 138, p. 378-411, 2005.

CARBONARI, C.; MESCHEDE, D. K.; VELINI, E. D. Efeitos da aplicação de glyphosate no crescimento inicial de mudas de eucalipto submetidas a dois níveis de adubação fosfatada. In: SIMPÓSIO INTERNACIONAL SOBRE GLYPHOSATE, 2007, Botucatu. Anais... Botucatu: FEPAF, 2007. p. 68-70.
COLOZZI-FILHO, A. Plantio direto: microorganismos e processos. In:ASSOCIAÇAO DE PLANTIO DIRETO NO CERRADO. Atualização em fertilidade e biodinâmica no sistema de plantio direto. Brasília: APDC, 2000. p. 29-42. Programa de treinamento.

CRUZ, J. C. Cultivo do milho: Sistema plantio direto. Sistemas de produção 2. Sete Lagoas 4 ed. Set. 2008. Disponível em: http://www.cnpms.embrapa.br/publicacoes/ milho/mandireto. htm> Acesso em: 03 abr. 2013.

FIGUEIREDO, S. S. et al. Influência de doses reduzidas de Glyphosate no tomateiro (Lycopersicon esculentum). Planta Daninha, v. 35, n. 03, p. 849-857, 2007.

GODOY, M. C. Efeitos do glyphosate sobre o crescimento e absorção de fósforo pela soja. 2007. 53 f. Dissertação (Mestrado em Agronomia) - Universidade Estadual Paulista (UNESP) Faculdade de Ciências Agrárias (FCA), Botucatu, 2007.

PIRES, R.F. et al. Manejo de plantas de cobertura antecessoras à cultura da soja em plantio direto. Revista Ceres, v. 55, n. 02 , p. 094-101, 2008.

SCHABENBERGER, O. et al. Statistical tests for hormesis and effective dosage in herbicide dose-response. Agronomy Journal, Madison, v. 91, p. 713-721, 1999.

SÁ, J. C. M. et al. Crescimento radicular, extração de nutrientes e produção de grãos de genótipos de milho em diferentes quantidades de palha de aveia-preta em plantio direto. Revista Brasileira de Ciência do Solo, v. 34, n. 04, p. 1207-1216, 2010.

SILVA, P. R. F. et al. Estratégias de manejo de coberturas de solo no inverno para cultivo do milho em sucessão no sistema semeadura direta. Ciência Rural, v. 36, n. 03, p. 1011-1020, 2006.

SILVA, P. I. B. et al. Acumulo de matéria seca de milho e braquiária consorciados em diferentes manejos de plantas daninhas. In: CONGRESSO BRASILEIRO DE PLANTAS DANINHAS, 27., 2010, Ribeirão Preto. Anais... Ribeirão Preto, 2010. p. 2351-2353.

SILVA, J. C. et al. Efeito hormese de glyphosate em feijoeiro. Pesquisa Agropecuária Tropical, v. 42, n. 03, p. 295-302, 2012.

TORRES, J. R. L. et al. Decomposição e liberação de nitrogênio de resíduos culturais de plantas de cobertura em um solo de cerrado. Revista Brasileira de Ciência do Solo, v. 29, n. 04, p. 609-618, 2005.

VELINI, E. D. Hormesis: is it an important factor in herbicide use and allelopathy?. Outlook on Pest Management, v. 17, n. 01, p. 29-33, 2006.

VELINI, E. D. et al. Glyphosate applied at low doses can stimulate plant growth. Pest Management Science, v. 64, n. 04, p. 489-496, 2008.

VIEIRA, S.; HOFFMANN, R. Estatística experimental. São Paulo: Atlas, 1989. 175 p.

WAGNER, R. M.; KOGAN, A. M. Parada Phytotoxic activity of root absorbed glyphosate in corn seedlings (Zea mays L.). Weed Biology Management, v. 03, n. 04, p. 228-232, 2003. 